\title{
THE INFLUENCE OF THE SEASON OF THE YEAR AND OF DILUTION ON THE DEVELOPMENT OF SWINE MANURE AND WOOD SHAVES CO-COMPOSTING
}

\author{
MARTHA M. HIGARASHI ${ }^{1}$, LUANA G. SARDÁ ${ }^{2}$, PAULO A. V. OLIVEIRA ${ }^{3}$
}

\begin{abstract}
The objective of this research was to study the influence of factors related to the proper management of pig manure (lower dilution) and the season of the year in the progress of the co-composting of pig manure with wood shavings and in the final quality of the compost resulting from the treatments. In the first experiment, two types of swine manure were used: a diluted one (2\% Dry Matter - DM), typical from the management usually used in Brazil, and a more concentrated one $(6 \% \mathrm{DM})$. The manures were incorporated into the wood shavings $(6 \mathrm{~L}: 1 \mathrm{~kg})$ over the course of four weeks. The development of composting was accompanied by monitoring of temperatures inside the piles and the emission of $\mathrm{CO}_{2}$ and $\mathrm{CH}_{4}$ gases during 65 days, including the period of incorporation. The results showed that the diluted manure does not provide the minimum conditions for starting the process. After the incorporation period, any biomass heating was observed and neither the aerobic or anaerobic respiration of the microorganisms, resulting in a compost with low quality. In the second experiment, which evaluated composting in winter and summer during 85 days, it was found that the heat exchange with the environment influences the temperature generated within the piles. The lower temperatures significantly reduced the methanogenesis on the biomass.
\end{abstract}

KEYWORDS: pig farming, manure management, compost, gas emission.

\section{INFLUÊNCIA DA ESTAÇÃO DO ANO E DA DILUIÇÃO NO DESENVOLVIMENTO DA COCOMPOSTAGEM DE DEJETOS DE SUÍNOS E MARAVALHA}

RESUMO: O presente trabalho buscou estudar a influência de fatores relacionados ao manejo adequado dos dejetos de suínos (redução da diluição) e à sazonalidade, no desempenho da cocompostagem de dejetos de suínos com maravalha e na qualidade final dos compostos resultantes dos tratamentos. No primeiro estudo, foram utilizados dois tipos de dejetos de suínos: um diluído (2\% Matéria Seca - MS), típico do manejo usualmente empregado no Brasil, e outro concentrado (6\% MS). Os dejetos foram sendo incorporados à maravalha (6 L: $1 \mathrm{~kg})$ no decorrer de 4 semanas. O desenvolvimento da compostagem foi acompanhado através dos monitoramentos das temperaturas no interior das pilhas e da emissão dos gases $\mathrm{CO}_{2}$ e $\mathrm{CH}_{4}$, durante 65 dias, incluindo o período da incorporação. Os resultados demonstraram que o dejeto diluído não fornece as condições mínimas para o desencadeamento do processo, não tendo sido observados o aquecimento da biomassa nem a respiração aeróbia ou anaeróbia dos microrganismos após o período de impregnação, resultando em um composto de baixa qualidade. No segundo estudo, no qual se avaliou a compostagem no inverno e no verão, durante 85 dias, constatou-se que a troca de calor com o ambiente tem influência na temperatura desenvolvida no interior das pilhas. As baixas temperaturas reduzem significativamente a atividade metanogênica na biomassa.

PALAVRAS-CHAVE: suinocultura, manejo de dejetos, composto, emissão de gases.

\footnotetext{
${ }^{1}$ Química, Doutora em Ciências, Pesquisadora, Embrapa Suínos e Aves, Concórdia - SC, martha@ cnpsa.embrapa.br.

${ }^{2}$ Eng $^{\mathrm{a}}$ Agrônoma, Mestre em Agroecossistemas, UFSC, Florianópolis - SC, luanasarda@ yahoo.com.br.

${ }^{3}$ Eng $^{\mathrm{o}}$ Agrícola, PhD em Ciências do Meio Ambiente, Pesquisador, Embrapa Suínos e Aves, Concórdia - SC, paolive@cnpsa.embrapa.br. 


\section{INTRODUCTION}

The modem Brazilian pig farming has been facing in recent years severe criticism regarding the environmental impact generated by the dramatic increase of its production scale, which led some regions to lodge animal populations over its carrying capacity (STEINFELD et al., 2006). This situation is aggravated by the fact that the practices and technologies employed in manure handling and management of the animals have not evolved at the same rate as other areas of production such as genetics, nutrition and health.

Animal waste, however, can be seen both as a residue highly damaging, as a promising source of nutrients for the production of agricultural inputs that can partially substitute finite mineral sources, whose prices are subject to fluctuations in international market (SILVA, 2008).

The proper fertilizer management and use of manure have a compulsorily balance of nutrients. So, after careful assessment, often the exports of the excess of the regions of high animal density turn out to be necessary. According to assessment in regions of high concentration of pigs in the country, in the state of Santa Catarina, the cost of exports of pig effluent is approximately 2.2 times higher than in the form of solid compound (OLIVEIRA \& HIGARASHI, 2006). Furthermore, the compound has fewer odors, reduces the proliferation of vectors and has a higher concentration of nutrients which, in turn, are less susceptible to leaching and percolation, reducing the risks of contamination of the water. Composting, therefore, may constitute an alternative treatment to the mitigation of the environmental impact of animal waste.

The conditions considered ideal for triggering the process of composting is a $\mathrm{C} / \mathrm{N}$ ratio from 20 to 35 and humidity of $45-60 \%$ (NPCC, 1991). Under these conditions, the exothermic metabolism of aerobic microorganisms increases the temperature of biomass as the microbial population grows, reaching ranges of mesophilic temperature $\left(30-40{ }^{\circ} \mathrm{C}\right)$ and even thermophilic (above $40^{\circ} \mathrm{C}$ ). Besides being an indicator of the progress of the composting process (FERNANDES et al., 1994), heat plays an important role in inactivation of seed pests and pathogenic microorganisms that may possibly be present in the raw materials for the process.

In its original form, the swine wastes are not suitable for composting, as they have inadequate moisture content and $\mathrm{C} / \mathrm{N}$ ratio (HUANG et al., 2004). The manure, as it is excreted, typically has $6.6 \%$ of $\mathrm{N}$ (dry weight basis) and $10 \%$ of solids with a $\mathrm{C} / \mathrm{N}$ ratio of about 7:1 (NPPC, 1991). Therefore, in order to obtain the minimum conditions to start the process, it is necessary to use devices such as the segregation of the solid fraction or the incorporation of carbon-rich substrates to the full waste (co-composting).

The substrates usually used in the co-composting are the shavings and sawdust, which have high content of molecules resistant to biodegradation (lignin and cellulose). Therefore, it is important to use fresh and concentrated manure in order to supply readily bioavailable organic matter to biomass composting, thus ensuring the departure of the process and the quality of the compost produced (RUDRUM, 2005).

The present research aimed to study, in a system of static windrow of pig manure cocomposting with sawdust, parameters that may influence: the activity of microorganisms (season of the year) and the quality of the resulting compound (dilution of the waste).

\section{MATERIAL AND METHODS}

\section{Composting platform}

The experiments were conducted on a composting platform located in the Demonstrative Unit of Embrapa Swine and Poultry in the city of Concordia, state of Santa Catarina $\left(27^{\circ} 18^{\prime} 46^{\prime \prime} \mathrm{S}\right.$, $\left.51^{\circ} 59^{\prime} 16^{\prime \prime} \mathrm{W}\right)$.

The platform consisted of a greenhouse structure of $8.0 \times 12.0 \mathrm{~m}$, constructed with transparent PVC covering, floor and internal masonry low walls and metal front gates. The installation was 
divided longitudinally by internal two low walls $0.80 \mathrm{~m}$ high, and the area was located in the middle, free for people and equipment transit (Figure 1).

\begin{tabular}{|c|l|l|}
\hline Composting cells & (1) & (2) \\
\hline \multicolumn{3}{|c|}{ Circulation area } \\
\hline \multicolumn{3}{|c|}{} \\
\hline Composting cells & (3) & (4) \\
\hline
\end{tabular}

FIGURE 1. Scheme of the facilities where the experiments were carried out.

The two lateral areas, both $2.5 \mathrm{~m}$ wide, were used as testing areas, where two cells/lateral of internal dimensions of $2.5 \mathrm{~m} \times 1.5 \mathrm{~m}$ x $0.8 \mathrm{~m}$ were mounted, using plywood to separate them. Trims were provided on the floor of masonry, to direct the runoff of the slurry from each of the cells to individual wells.

The compost piles were assembled in the cells, and the raw materials used for the composition of biomass were eucalyptus shavings and pig manure from a demo farm, located next to the composting platform, composed of 14 matrices under the complete cycle.

\section{Influence of dilution of the manure composting}

The experiments were conducted between May and July 2009 using waste resulting from different management systems within the animals' facility: the first, which took place a management usually used in Brazil with daily washing of floors, and the second handling, in which tried to reduce the use of water, using scraping of the floor in the place of washing. Both wastes were sampled and analyzed at the Demonstrative Unit of Embrapa Swine and Poultry, using official standardized methodologies (EATON et al., 1995), for the parameters: organic carbon (OC), dry matter (DM), total nitrogen $\left(\mathrm{N}_{\mathrm{T}}\right)$ and series of solid - total (TS), fixed (FS) and volatile (VS).

TABLE 1. Weighted average composition of diluted and concentrated manures used in the experiment.

\begin{tabular}{lcccccc}
\hline & $\mathrm{OC}\left(\mathrm{g} \mathrm{L}^{-1}\right)$ & $\mathrm{DM}(\%)$ & $\mathrm{N}_{\mathrm{T}}\left(\mathrm{g} \mathrm{L}^{-1}\right)$ & $\mathrm{TS}\left(\mathrm{g} \mathrm{L}^{-1}\right)$ & $\mathrm{FS}\left(\mathrm{g} \mathrm{L}^{-1}\right)$ & $\mathrm{VS}\left(\mathrm{g} \mathrm{L}^{-1}\right)$ \\
\cline { 2 - 6 } Diluted Wastes & $13.3 \pm 2.41$ & $2.17 \pm 0.06$ & $2.6 \pm 0.4$ & $22.5 \pm 0.49$ & $6.60 \pm 0.50$ & $15.9 \pm 0.78$ \\
Concentrated Wastes & $21.0 \pm 5.06$ & $6.06 \pm 3.57$ & $3.8 \pm 0.3$ & $53.3 \pm 0.39$ & $17.0 \pm 2.3$ & $36.3 \pm 9.32$ \\
\hline
\end{tabular}

Two piles were constructed for each treatment (diluted and concentrated). The manure application for wood shavings was made according to the methodology described by NUNES (2003), where the manure was incorporated into the substrate in doses divided into four portions (1 portion/week), interspersed with additions for two days until achieve the proportion of $6 \mathrm{~L}$ of waste: $1 \mathrm{~kg}$ of sawdust. In the first week, it was added the equivalent of $40 \%$ of the total to be impregnated, $30 \%$ in the second, $20 \%$ in the third, and $10 \%$ in the last week. The slurry drained from the piles was daily collected from the drains installed in the cells and reinstated to the respective cells.

Three parameters were used to monitor the performance of composting in the two treatments studied: the temperature generated inside the cells and the emission of the $\mathrm{CO}_{2}$ and $\mathrm{CH}_{4}$ gases, which are indicative of aerobic and anaerobic microbial activity of the system.

For measuring the temperature, thermocouples of wire Copper Constantan were inserted within each cell to a depth of $30 \mathrm{~cm}$, and the readings were taken every day at the same time 
(10 am). Measurements of $\mathrm{CO}_{2}$ and $\mathrm{CH}_{4}$ emission were performed using the methodology of static camera at three points/pile (SARDÁ et al., 2010), with readings taken at 3 minutes/point (Figure 2), made daily in the morning, between 10 and 11 am during 65 days, 21 days of which corresponded to the period of impregnation, followed by 45 days corresponding to the stabilization step.

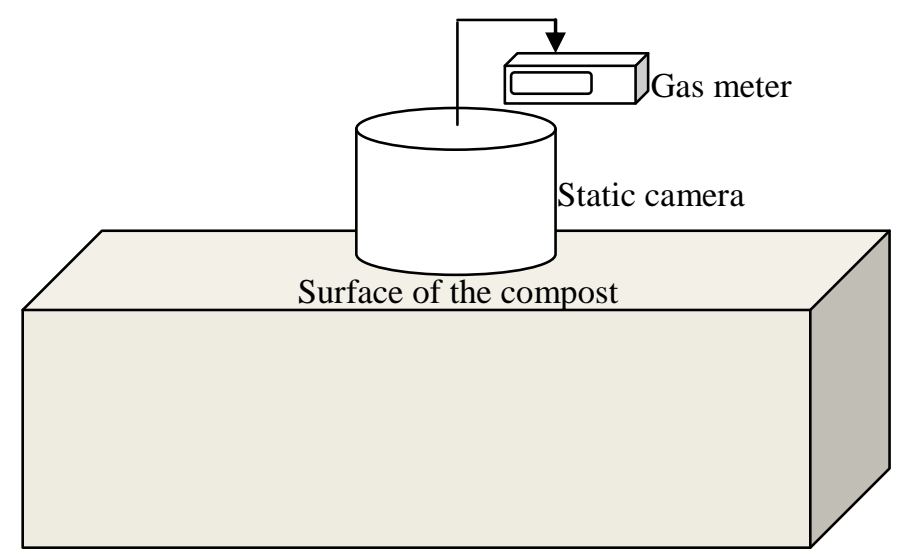

FIGURE 2. Static chamber method used to measure gases emission from the composting cell.

The equipment used to measure the emission of gases was equipped with a portable infrared detector for methane and carbon dioxide (Draeger X-am 7000 model). The data of the increase of gases concentrations in the chamber were used to calculate the flow according to SOMMER \& MØLLER (2000), using equation (1):

$$
\mathrm{F}=\frac{V}{A} \quad \frac{\Delta C}{\Delta t}
$$

In which: $V=$ volume of the chamber $\left(\mathrm{m}^{3}\right), A=$ surface area covered by the camera $\left(\mathrm{m}^{2}\right), \frac{\Delta C}{\Delta t}=$ rate of increase in the concentration of gas in the headspace of the chamber in relation to the time that the surface remains covered $\left(\mathrm{gm}^{-3}\right.$ per $\left.\mathrm{min}\right)$. The gases emission rates by windrow (kg per windrow day) were calculated from these flow values.

After 60 days from the beginning of the experiment, samples were collected from each of the piles, after careful revolving in order to evaluate the quality of the compound produced as the concentration of nutrients. The samples were sent to the laboratory of physical-chemical analyzes of the Demonstrative Unit of Embrapa Swine and Poultry, where they were processed and analyzed according to official standard methods (EATON et al., 1995; AOAC, 1995) for the following parameters: total nitrogen $\left(\mathrm{N}_{\mathrm{T}}\right)$ phosphorus $(\mathrm{P})$, potassium $(\mathrm{K})$, organic carbon $(\mathrm{OC})$, moisture and $\mathrm{pH}$.

\section{Influence of season of the year}

To evaluate the influence of seasonality in the development of composting of pig manure, two experiments were conducted at different times of the year. Both assays were performed with two replicates in the composting platform at the Demonstrative Unit of Embrapa Swine and Poultry, according to the monitoring and impregnation procedures as described above.

The summer experiment was conducted between October and December 2008, and the winter experiment from May to July 2009. Since the studies were developed at different times using different batches of raw materials, it was performed a preliminary evaluation of those, in which it was determined the specific weight of wood shavings of the two lots used, and at each impregnation, it was analyzed the $\mathrm{N}_{\mathrm{T}}$ and the series of solid waste (Table 2). 
TABLE 2. Weighted average composition of the raw materials used in the experiments of summer and winter.

\begin{tabular}{lccccc}
\hline Season & \multicolumn{4}{c}{ Wastes } & Wood Shaving \\
\cline { 2 - 6 } & $\mathrm{N}_{\mathrm{T}}\left(\mathrm{g} \mathrm{L}^{-1}\right)$ & $\mathrm{TS}\left(\mathrm{g} \mathrm{L}^{-1}\right)$ & $\mathrm{VS}\left(\mathrm{g} \mathrm{L}^{-1}\right)$ & $\mathrm{FS}\left(\mathrm{g} \mathrm{L}^{-1}\right)$ & Specific Weight $\left(\mathrm{kg} \mathrm{m}^{-3}\right)$ \\
\hline Summer & $3.55 \pm 0.630$ & $42.3 \pm 9.00$ & $31.6 \pm 7.60$ & $10.6 \pm 1.90$ & $183 \pm 3.00$ \\
Winter & $3.81 \pm 0.570$ & $51.5 \pm 17.1$ & $34.6 \pm 12.9$ & $16.9 \pm 4.40$ & $136 \pm 5.00$ \\
\hline
\end{tabular}

As the amount of wood shavings/cell was based on the volume of cells $\left(3 \mathrm{~m}^{3}\right)$ and, in view of the difference in specific weight of the two lots of wood shavings used, the summer experiment consumed $558 \mathrm{~kg}$ of wood shavings and $3.34 \mathrm{~m}^{3}$ of wastes $(6 \mathrm{~L}$ waste/1 kg of wood shavings), while the winter experiment used $408 \mathrm{~kg}$ of wood shavings and $2.45 \mathrm{~m}^{3}$ of wastes.

The procedures of impregnation, monitoring of the composting, sampling and analysis followed the same protocols described in the experiment to evaluate the influence of dilution.

\section{RESULTS AND DISCUSSION}

\section{Influence of the waste dilution}

The evolution of the temperature of the biomass during composting, shown in FIGURE 3 shows that waste dilution interfere with the efficiency of the process during impregnation (until the $20^{\text {th }}$ day), and this influence is further evidenced during the maturation period.

In the pile in which the most concentrated manure was incorporated, there was a greater increase in temperature in each impregnation, reaching levels in the order of $50{ }^{\circ} \mathrm{C}$. After the impregnation step, the temperature was maintained between approximately $40{ }^{\circ} \mathrm{C}$ throughout the study period.

The pile with the most diluted manure, on the other hand, showed only slight elevations in temperature during the impregnation period, rarely exceeding $40{ }^{\circ} \mathrm{C}$. Elapsed this step, the temperature fell and stabilized, remaining near ambient temperature inside the platform $\left(20^{\circ} \mathrm{C}\right.$ $\left.30^{\circ} \mathrm{C}\right)$.

According to BERNAL et al. (2009) the optimum temperature range for composting is between $40-65^{\circ} \mathrm{C}$, and temperatures above $55^{\circ} \mathrm{C}$ are required for inactivation of pathogens.

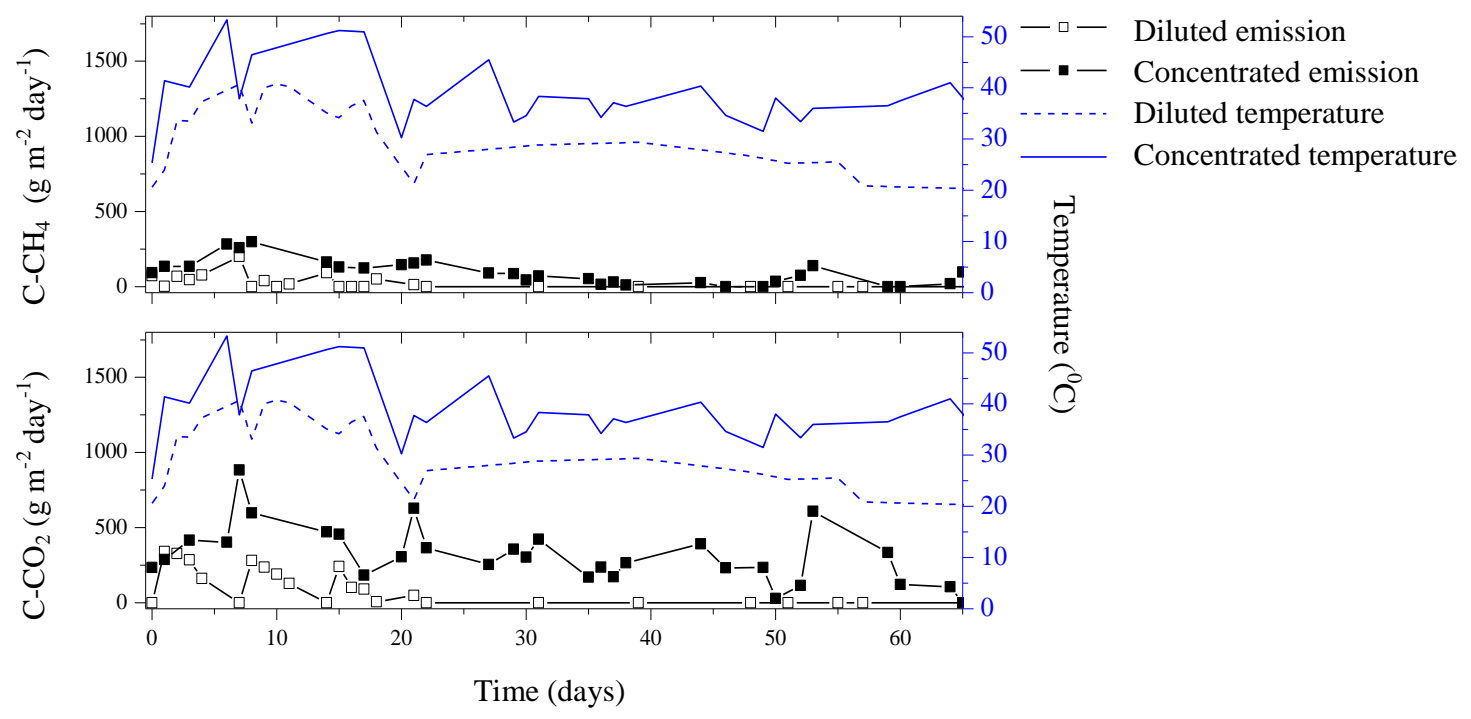

FIGURE 3. Temperature inside the piles and $\mathrm{C}-\mathrm{CO}_{2}$ and $\mathrm{C}-\mathrm{CH}_{4}$ emissions from the composting of diluted and concentrated swine manure. 
In the mesophilic $\left(30{ }^{\circ} \mathrm{C} \leq \mathrm{t} \leq 40{ }^{\circ} \mathrm{C}\right)$, mainly mediated by bacteria and fungi, is the degradation of simpler compounds such as sugars, amino acids and proteins, which means that there is a rapid increase in temperature, then going to thermophilic phase $\left(\mathrm{t}>40{ }^{\circ} \mathrm{C}\right)$, which occurs in the establishment and development of populations of microorganisms (mainly fungi and actiomicetos) able to metabolize more recalcitrant organic molecules such as cellulose, hemicellulose and, in a lower proportion, lignin.

The results showed that the composting with diluted manure stopped in the mesophilic stage, which is achieved only during the impregnation phase and, after this period, the temperature of the piles balances with the ambient, and the process does not proceed.

Data on emissions of $\mathrm{CO}_{2}$ and $\mathrm{CH}_{4}$ which, in the first instance, would correspond to the respiration of microorganisms, also shown in Figure 3, corroborate a hypothesis of the absence of microbiological activity (both aerobic and anaerobic) after the period of impregnation on the pile containing the diluted manure, since it was not detected any emission of both $\mathrm{CO}_{2}$ and $\mathrm{CH}_{4}$ after the $21^{\text {st }}$ day. Therefore, the concentration of the manure has a direct influence on the starting process and, consequently, the development of composting as a whole, since the steps succeed in chain.

During the starting, when it is not provided a sufficient amount of bioavailable organic matter for the temperature rise and the establishment of microbial populations capable of sustaining the natural evolution of composting, the process stops as soon as the addition of biodegradable organic matter is adjourned, which is supplied mainly by manure. As a consequence, the biomass does not go through the thermophilic stage and maturation, both essential to ensure the stability and health security of the final product.

The quality evaluation of compounds on the content of nutrients and organic matter (Table 3) was conducted after about 65 days after the beginning of the treatment.

TABLE 3. Composition of the composts on dry basis resulted from concentrated manure (1) and diluted manure (2) incorporated to wood shaving (6L manure $/ 1 \mathrm{~kg}$ of bulking) after 60 days.

\begin{tabular}{lccccccc}
\hline Wastes & $\mathrm{K}\left(\mathrm{g} \mathrm{kg}^{-1}\right)$ & $\mathrm{N}_{\mathrm{T}}\left(\mathrm{g} \mathrm{kg}^{-1}\right)$ & $\mathrm{P}_{\mathrm{T}}\left(\mathrm{g} \mathrm{kg}^{-1}\right)$ & $\mathrm{OC}(\%)$ & $\mathrm{C} / \mathrm{N}$ & Humidity $(\%)^{*}$ & $\mathrm{pH}$ \\
\cline { 2 - 7 } (1) Diluted & 2.9 & 5.9 & 3.14 & 35.5 & 60.5 & 65.9 & 7.1 \\
(2) Concentrated & 13.1 & 14.7 & 17.30 & 42.2 & 28.8 & 66.6 & 6.8 \\
\hline
\end{tabular}

"Humidity determined by drying at $65^{\circ} \mathrm{C}$.

The results showed that the compound produced from more concentrated manure, as expected, has significantly greater amounts of nutrients.

The $\mathrm{C} / \mathrm{N}$ ratio found for the compound (2) was 28.8 , while for the (1) was 60.5 . According to HUANG et al. (2004), the biomass composting with a too high $\mathrm{C} / \mathrm{N}$ rate has a slower temperature rise, reaches lower maximum temperatures and thermophilic stage of short duration, which is in agreement with the behavior observed for composting with diluted waste.

According to the Normative Instruction No.25 of July $23^{\text {rd }}, 2009$, the maximum C/N rate required by the Ministry of Agriculture, Livestock and Food Supply for a fertilizer compound is 20 (BRASIL, 2009), so both compounds analyzed were above the value required. Similarly, their moisture content above the maximum were established by law $(50 \%)$, indicating the need for a period longer than 65 days to complete maturation and the compound cure.

According to the data of $\mathrm{CO}_{2}$ and $\mathrm{CH}_{4}$ during the study period, the resulting biomass of concentrated waste (2) remained with the biological activity active, with evidence of continuity. Thus, compound (2) continues to suffer the same changes which lead it to eventually reach the level of maturation required by law. The compound (1), on the other hand, may still lose some moisture and ammonia nitrogen during maturation, but the organic fraction of it should not change much over time, since there was no microbiological activity after the period of impregnation (Figure 3). 
Moreover, its $\mathrm{C} / \mathrm{N}$ ratio excessively high, the lowest concentration of nutrients and the low temperature rise observed in the process demonstrate that in the composting which uses diluted pig manure will result in a product of lesser quality both from the fertilizer and sanitary aspect.

\section{Influence of season of the year}

The monitoring of ambient temperatures and piles in the winter and summer (Figure 4) showed that during the impregnation of the manure to the substrate (up to the $21^{\text {st }}$ day), the temperature of the biomass in both seasons showed large oscillations due to the periodic addition of manure and revolving. The ambient temperature during impregnation were not so different in the two periods, standing at $16.4 \pm 5.0^{\circ} \mathrm{C}$ in the winter and $19.7 \pm 2.0^{\circ} \mathrm{C}$ in the summer. Thus, there were also no major differences in the average temperature of the biomass between the two periods, with a mean value in the winter of $41.8 \pm 8.9^{\circ} \mathrm{C}$, and $42.0 \pm 6.2^{\circ} \mathrm{C}$ in the summer.

At maturation, on the other hand, the temperatures shown to be differentiated, with a mean value of $14.9 \pm 3.0^{\circ} \mathrm{C}$ in the winter and $22.6 \pm 2.8^{\circ} \mathrm{C}$ in the summer. Likewise, the temperatures of biomass during these periods reflected an outstanding difference, with mean values of $36.1 \pm 3.3{ }^{\circ} \mathrm{C}$ and $50.3 \pm 4.4^{\circ} \mathrm{C}$ in the winter and summer, respectively.

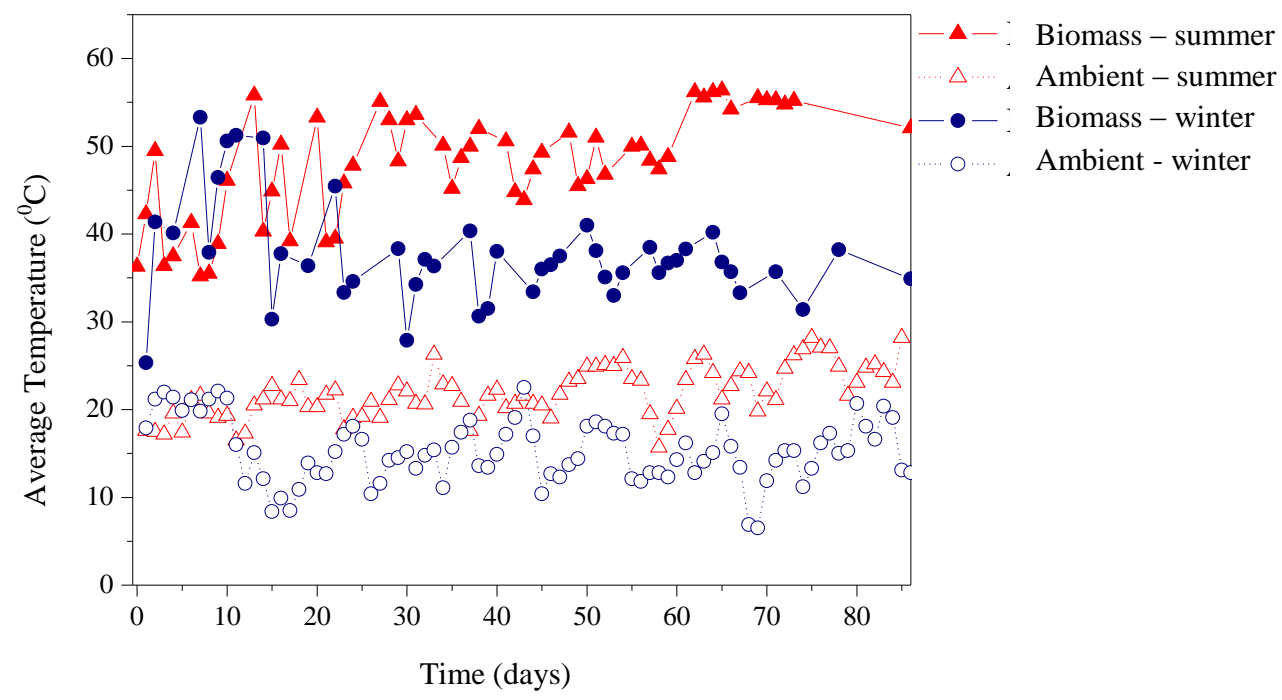

FIGURE 4. Profile of the temperature developed inside the composting piles and average temperature in region of Concórdia, state of Santa Catarina, from October to December/2008 (summer) and from May to July/2009 (winter).

These results demonstrate that the temperature affects the development of temperatures within the piles. Thus, despite the exothermic biological processes, inherent in the compost, are primarily responsible for producing the heat required for the development of the process, the heat exchange with the environment affects the performance of the treatment. Possibly this effect was easily observed due to the relatively small scale in which the studies were conducted $\left(3 \mathrm{~m}^{3}\right)$. In piles containing larger amounts of biomass, the effect of surface heat exchange should be minimized because of the large amount of heat generated inside the piles and greater retention capacity of the thick layer of wood shavings, a known insulator (HIGARASHI et al., 2011).

On the other hand, when the composting is conducted on a large scale due to the higher compression, it is necessary to take measures to supply oxygen to the system, such as turning, passive aeration or forced air injection, among others. These measures are required to prevent the prevalence of anaerobic conditions inside the cells, which would result in several problems, such as the proliferation of flies, issuance of bad odors, fluidization of biomass (slurry generation) and of low quality fertilizers, among other. 
On the scale in which the work has been conducted, although it was not performed any intervention after impregnation, the aerobic processes prevailed over the anaerobes, as verified by the results of emission of $\mathrm{C}-\mathrm{CO}_{2}$ and $\mathrm{C}-\mathrm{CH}_{4}$ shown in Figures 5 and 6.

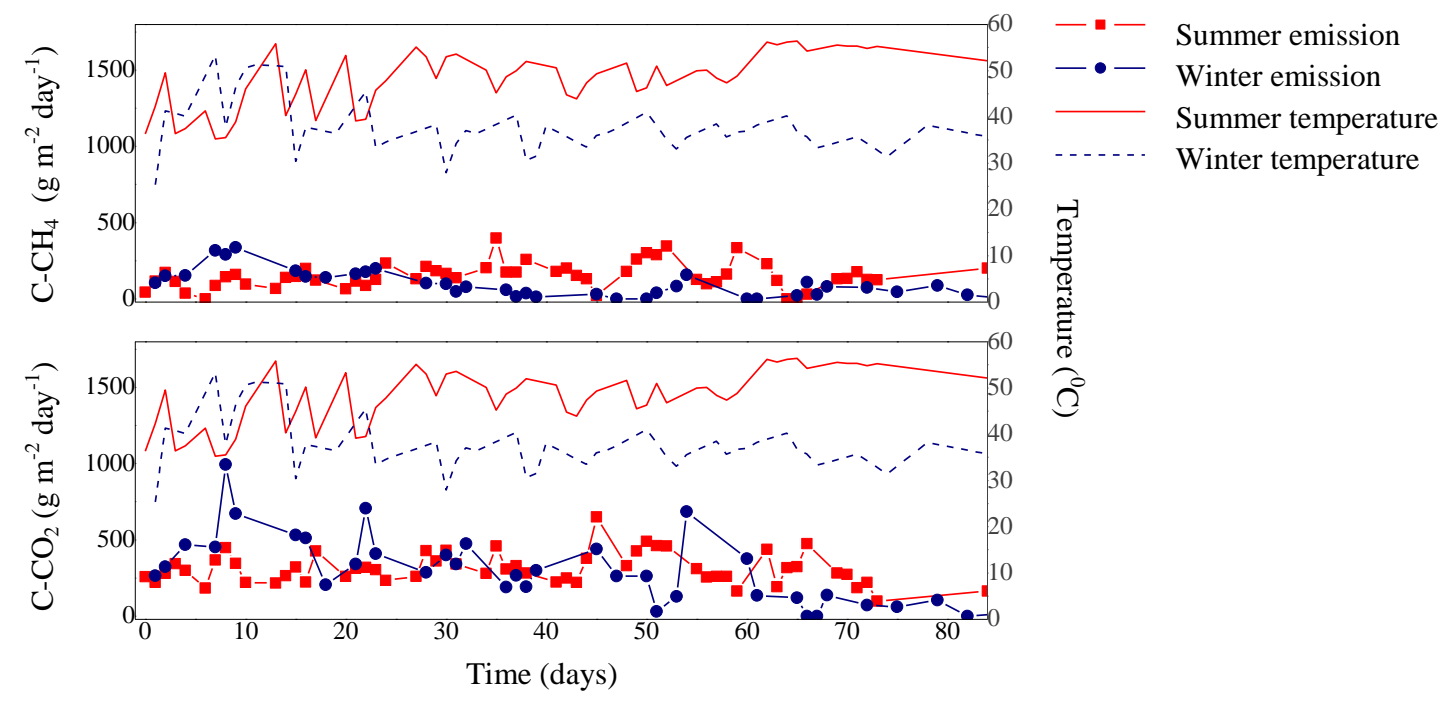

FIGURE 5. Profile of $\mathrm{C}-\mathrm{CH}_{4}$ and $\mathrm{C}-\mathrm{CO}_{2}$ emissions during co-composting of swine manure with wood shavings and temperature development inside the composting piles during winter and summer.

During the impregnation, the experiment conducted in the winter showed a greater emission of $\mathrm{C}-\mathrm{CH}_{4}$ and $\mathrm{C}-\mathrm{CO}_{2}$ (FIGURE 5). This result was unexpected, since higher temperatures favor microbiological activity. Possibly, this higher initial emission of gases observed in the winter was not due to biological questions, but to physical processes resulting from the higher compression cell mounted in the summer because of the higher specific weight of wood shavings used in this period (Table 2).

Several studies have reported significant reductions in gases emission with increased compaction of the waste or manure storage. This phenomenon occurs because the reduction in pore spaces filled with air, which prevents or discourages gas exchange (EL KADER et al., 2007). However, according to CHADWICK (2005), a larger compression reduces the emission of $\mathrm{CH}_{4}$ only in the initial period of storage, given that in the final period, the compacting would favor methanogenesis, and the total balances of $\mathrm{CH}_{4}$ emission would eventually be equivalent in both cells in a higher or lower degree of compression.

The results (Figure 6) confirm the dominance of aerobic processes with emissions of $\mathrm{C}-\mathrm{CO}_{2}$ greater than the $\mathrm{C}-\mathrm{CH}_{4}$ in about $48 \%$ in summer and $68 \%$ in winter. The cumulative emissions of C$\mathrm{CO}_{2}$ during the 85 days were nearly equal, both in winter and summer, which is in agreement with the literature (CHADWICK, 2005). Therefore, the difference between the two periods is by inhibition of $\mathrm{CH}_{4}$ emission in the winter. Thus, although there is a greater initial emission of C- $\mathrm{CH}_{4}$ in winter, probably due to the lower compression of biomass, the accumulated emission of $\mathrm{CH}_{4}$ in the 85-day trial was lower in winter. 


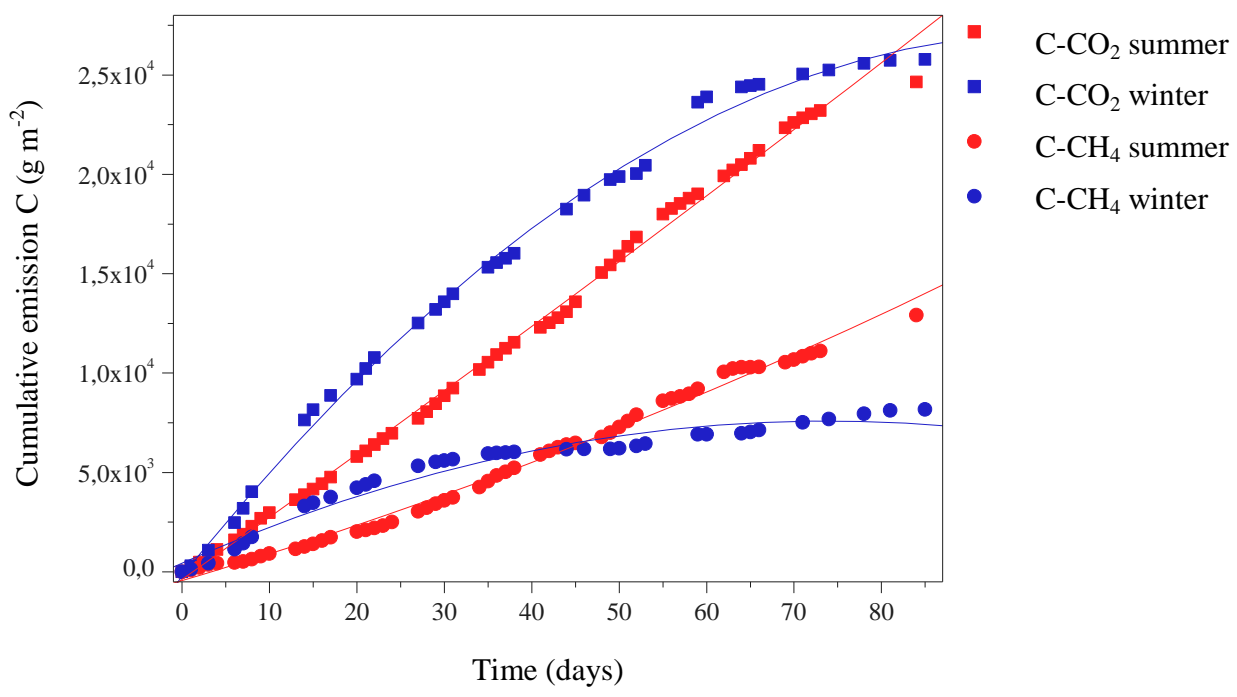

FIGURE 6. Cumulative emissions of $\mathrm{C}-\mathrm{CO}_{2}$ and $\mathrm{C}-\mathrm{CH}_{4}$ during co-composting of swine manure incorporated into wood shavings in winter and summer.

The proportions of $\mathrm{C}-\mathrm{CH}_{4}$ emission with respect to $\mathrm{C}_{\text {total }}$ emitted was $34.4 \%$ in the summer $\left(\mathrm{t}_{\text {mean }}=19.7 \pm 2.0^{\circ} \mathrm{C}\right)$ and $24.1 \%$ in the winter $\left(\mathrm{t}_{\text {mean }}=16.4 \pm 5,0{ }^{\circ} \mathrm{C}\right)$. Reductions in the proportion of $\mathrm{CH}_{4}$ in the winter had been reported in previous studies, MOLLER et al. (2004), for example, evaluated the emission of storage systems of open and aerated manure during 90 days and showed that the proportion of carbon emitted by anaerobic $\left(\mathrm{C}-\mathrm{CH}_{4}\right)$ increased from $31.2 \%$ to $39 \%$ with increase in temperature of $15^{\circ} \mathrm{C}$ to $20^{\circ} \mathrm{C}$.

TABLE 4. Composition of the composts on dry basis resulted from experiments conducted in the summer (1) and in the winter (2) after 120 days.

\begin{tabular}{lccccccc}
\hline Wastes & $\mathrm{K}\left(\mathrm{g} \mathrm{kg}^{-1}\right)$ & $\mathrm{N}_{\mathrm{T}}\left(\mathrm{g} \mathrm{kg}^{-1}\right)$ & $\mathrm{P}_{\mathrm{T}}\left(\mathrm{g} \mathrm{kg}^{-1}\right)$ & $\mathrm{OC}(\%)$ & $\mathrm{C} / \mathrm{N}$ & Humidity $(\%)^{*}$ & $\mathrm{pH}$ \\
\cline { 2 - 7 } (1) Summer & 6.8 & 16.8 & 14.5 & 37.6 & 25.9 & 59.7 & 6.9 \\
(2) Winter & 13.1 & 14.7 & 17.3 & 42.2 & 28.8 & 66.6 & 6.8 \\
\hline
\end{tabular}

As shown in TABLE 4, the resulting composts of the treatments do not differ significantly from the point of view of nutrient contents. As the wastes used in winter present themselves less diluted, similarly the compost (2) showed higher amounts of fixed nutrients $\left(\mathrm{K}, \mathrm{P}_{\mathrm{T}}\right)$ than the compost (1). However, considering the $\mathrm{C} / \mathrm{N}$ ratio, the compost (1) presented itself in a more advanced stage of stabilization. Moreover, the higher temperatures attained by the biomass in the process developed in the summer (Figure 5) provide greater sanitary safety to the compost (1) in accordance with the recommendation of the USEPA (1985), which establishes the minimum time and temperature for the composting of urban sewage sludge of $55^{\circ} \mathrm{C}$ for three consecutive days.

\section{CONCLUSIONS}

The high dilution of swine manure may technically make impossible its co-composting with wood shavings for not providing the minimum conditions for the development of microorganisms responsible for triggering the process. Therefore, management of water within the animal installations is a decisive factor for the viability of the use of composting in waste treatment.

The surface heat exchange between the environment and biomass makes the ambient temperature to affect the maximum temperature reached within the biomass. In winter, temperatures in the composting were lower, reducing the health guarantees of the compost. From the standpoint of microbiological activity, according to gases emission monitoring, the lower temperatures only inhibit the anaerobic processes of the system. 


\section{FINAL CONSIDERATIONS}

It is extremely important to pay attention to the risks of deploying new technologies in the field based on purely empirical management practices, without considering the appropriate technical criteria. Such practices can irreparably impair the credibility of a promising technology due to the indiscriminate entrance in the market for compounds of low agronomic quality, and it is complicated by the lack of health guarantees - presence of pathogens and weed seeds, among others.

\section{REFERENCES}

AOAC. ASSOCIATION OF OFFICIAL ANALYTICAL CHEMISTS. Official Methods of Analysis of AOAC International. Arlington, 1995. $190 \mathrm{p}$.

BERNAL, M.P.; ALBUQUERQUE, J.A.; MORAL, R. Composting of animal manures and chemical criteria for compost maturity assessment. A review. Bioresource Technology, Oxford, v.100, p.5444-5453, 2009.

BRASIL. Ministério da Agricultura Pecuária e Abastecimento - MAPA. Instrução Normativa n. 25, 23 Julho de 2009. Disponível em: <http://extranet.agricultura.gov.br/sislegis/>. Acesso em: 19 jul. 2010.

CHADWICK, D.R. Emissions of ammonia, nitrous oxide and methane from cattle manure heaps: effect of compaction and covering. Atmosferic Environment, Oxford, v.39, p.787-799, 2005.

EATON, A.D.; CLESCERI, L.S.; GREENBERG, A.E. (Ed.) Standard methods for the examination of water and wastewater. $19^{\text {th }}$ ed. Washington: American Public Health Association, 1995. 1325 p.

EL KADER, N.A.; ROBIN, P.; PAILLAT, J.M.; LETERME, P. Turning, compacting and the addition of water as factors affecting gaseous emissions in farm manure composting. Bioresource Technology, Oxford, v.98, p.2619-2628, 2007.

FERNADES, L.; ZHAN, W.; PATNI, N.K.; JUI, P.Y. Temperature distribution and variation in passively aerated static compost piles. Bioresource Technology, Oxford, v.48, p.257-263, 1994.

HIGARASHI, M.M.; SARDÁ, L.G.; OLIVEIRA, P.A.V.; MATTEI, R.M.; COMIN, J.J. Avaliação do desempenho da maravalha e da palha de azevém (Lollium multiflorum) como substratos na cocompostagem de dejetos de suínos. In: SIMPÓSIO INTERNACIONAL SOBRE GERENCIAMENTO DE RESÍDUOS AGROPECUÁRIOS E AGROINDUSTRIAIS, 2., 2011, Foz do Iguaçú. Anais... Concórdia: SBERA, 2011. 1 CD-ROM.

HUANG, G.F.; WONG, J.W.C.; WU, Q.T.; NAGAR, B.B. Effect of C/N on composting of pig manure with sawdust. Waste Management, Oxford, v.24, p.805-813, 2004.

MOLLER, H.B.; SOMMER, S.G.; AHRING, B.K. Biological degradation and greenhouse gas emissions during pre-storage of liquid animal manure. Journal of Environmental Quality, Madison, v.33, p.27-36, 2004.

NPCC. NATIONAL PORK PRODUCERS COUNCIL. Swine Manure Composting Environmental Assurance Program. Washington: NPPC, 1991. 53 p.

NUNES, M.L.A. Avaliação de procedimentos operacionais na compostagem de dejetos de suínos. 117 f. Dissertação (Mestrado em Engenharia Ambiental) - Universidade Federal de Santa Catarina, Florianópolis, 2003.

OLIVEIRA, P.A.V.; HIGARASHI, M.M. Unidade de compostagem para o tratamento de dejetos de suínos. Concórdia: EMBRAPA/CNPSA, 2006. 39 p. (Documents, 114).

RUDRUM, D. Innovations in composting pig manure. 2005. $170 \mathrm{f}$. Tese (Doutorado) - Wageningen University, Wageningen, Holanda, 2005. 
SARDÁ, L.G.; HIGARASHI, M.M.; MULLER, S.; OLIVEIRA, P.A.V.; COMIN, J.J. Redução da emissão de $\mathrm{CO}_{2}, \mathrm{CH}_{4}$ e $\mathrm{H}_{2} \mathrm{~S}$ através da compostagem de dejetos suínos. Revista Brasileira de Engenharia Agrícola e Ambiental, Campina Grande, v.14, n.9, p.1008-1013, 2010.

SILVA, S. Governo quer conter os preços de fertilizantes - Retomada de jazidas e corte de impostos de importação estão entre as medidas. Jornal Correio de Uberlândia, Uberlândia, 22, jul. 2008.

SOMMER, S.V.; MOLLER, H.B. Emissions of greenhouse during composting of deep litter from pig productions - effect of straw content. Journal of Agricultural Sciences, v.134, p.327-335, 2000.

STEINFELD, H.; GERBER, P.; WASSENAAR, T.; CASTEL, V.; ROSALES, M.; HAAN, C. Livestock's long shadow - environmental issues and options. Roma: FAO, 2006. 391 p.

USEPA. UNITED STATES ENVIRONMENTAL PROTECTION AGENCY. Composting municipal wastewater sludges, EPA/ 625/4-85/014. Washington, 1985. 66 p. 


\section{ERRATA: volume 32, número 2}

p.241 onde se lê:

$$
\mathrm{CO}^{2} \text { and } \mathrm{CH}^{4}
$$

\section{Leia-se:}

$\mathrm{CO}_{2}$ and $\mathrm{CH}_{4}$ 